\title{
NARRATIVA VISUAL: MEDIAÇÃO DE LEITURA NA EDUCAÇÃO INFANTIL ${ }^{1}$
}

\author{
NARRATIVA VISUAL: MEDIACIÓN DE LECTURA EN LA EDUCACIÓN INFANTIL \\ VISUAL NARRATIVE: READING MEDIATION IN EARLY CHILDHOOD \\ EDUCATION
}

\author{
Fabiana Lazzari LORENZET ${ }^{2}$ \\ Flávia Brocchetto RAMOS ${ }^{3}$ \\ Renata Junqueira de SOUZA ${ }^{4}$
}

RESUMO: Com a meta de contribuir para os processos de letramento de crianças de 4 anos, investiga-se peculiaridades acerca do modo como leem a narrativa visual "Ladrão de galinha", de Béatrice Rodriguez. A pesquisa tem abordagem qualitativa e exploratória e parte da seleção e análise de um título integrante do acervo de Educação Infantil do PNBE/2014, seguida de construção e vivência coletiva de proposta de mediação de leitura, a fim de analisar como as crianças pequenas atuam no processo de construção de sentido de narrativas visuais, em situações de mediação planejadas. Como resultados do estudo, apontamos contribuições da leitura literária do livro de imagens no cotidiano escolar de crianças em idade pré-escolar. As crianças complementam, convergem, divergem, expressam suas opiniões, quer seja pela fala ou por outras formas de expressão. O livro de imagens mostrouse valioso objeto cultural que contribui para a promoção da interação e da autonomia.

PALAVRAS-CHAVE: Mediação. Leitura literária. Educação infantil.

RESUMEN: Con el objetivo de contribuir a los procesos de alfabetización (literacidad) de niños de 4 años, este artículo investiga peculiaridades acerca del modo como niños de esa edad leen la narrativa visual "Ladrão de galinha", de Béatrice Rodríguez. La investigación tiene un enfoque cualitativo y exploratorio y parte de la selección y análisis de un título integrante del acervo de Educación Infantil del Programa Nacional Biblioteca de la Escuela (PNBE) 2014, seguida de construcción y aplicación de propuesta de mediación de lectura con niños colectivamente, a fin de analizar cómo actúan en el proceso de construcción de sentido de narrativas visuales, a partir de situaciones de mediación planeadas intencionalmente. Como resultados del estudio, señalamos contribuciones de la lectura

1 Artigo produzido no âmbito de projetos aprovados pelo processo: 309178/2019-3 Demanda/Chamada: Chamada CNPq 06/2019 - Bolsas de Produtividade em Pesquisa Modalidade: PQ Categoria/Nível: 2 e pelo Edital FAPERGS: 02/2017 - PqG (termo de outorga 17/2551-0001 115-5).

2 Universidade de Caxias do Sul (UCS), Caxias do Sul - RS - Brasil. Doutoranda no Programa de PósGraduação em Educação. ORCID: https://orcid.org/0000-0003-0350-6683. E-mail: fabianalazzari@yahoo.com.br

${ }^{3}$ Universidade de Caxias do Sul (UCS), Caxias do Sul - RS - Brasil. Docente no Programa de Pós-Graduação em Educação. Doutorado em Linguística e Letras (PUCRS). Bolsista de Produtividade em Pesquisa do CNPq Nível 2. ORCID: https://orcid.org/0000-0002-1488-0534. E-mail: ramos.fb@gmail.com

${ }^{4}$ Universidade Estadual Paulista (UNESP), Presidente Prudente - SP - Brasil. Livre-docente. Doutorado em Letras (UNESP). Bolsista de Produtividade em Pesquisa do CNPq - Nível 2. ORCID: https://orcid.org/00000003-2227-2544.E-mail: recellij@gmail.com 
literaria del libro de imágenes en el cotidiano escolar de niños en edad preescolar. También verificamos que los niños, en situaciones de interacción, auxilian, complementan, convergen, divergen, expresan sus opiniones tanto por el habla como por otras formas de expresión. En síntesis, el libro de imágenes se mostró valioso objeto cultural que promueve la interacción y la autonomía.

PALABRAS CLAVE: Mediación. Lectura literaria. Educación infantil.

ABSTRACT: With the goal of contributing to the literacy processes of 4-year-old children, this article investigates peculiarities about how children of that age read the visual narrative of "Ladrão de galinha" (Chicken Thief) by Béatrice Rodriguez. The research has a qualitative and exploratory approach and part of the selection and analysis of an integral part of the Program's Early Childhood Collection National Library of the School (PNBE) 2014, followed by construction and application of a proposal for mediation of reading with children in groups, in order to analyze how they act in the process of construction of sense of visual narratives, from intentionally planned situations of mediation. As a result of the study, we point out contributions from the literary reading of the picture book in the daily school life of pre-school children. We also verify that children, in situations of interaction, help, complement, converge, diverge, express their opinions through speech or other forms of expression. In summary, the book of images proved to be a valuable cultural object that promotes interaction and autonomy.

KEYWORDS: Mediation. Literary reading. Early childhood education.

\section{Introdução}

[...] toda palavra comporta duas faces. Ela é determinada tanto pelo fato de que procede de alguém, como pelo fato de que se dirige para alguém. Ela constitui justamente o produto da interação do locutor e do ouvinte. Toda palavra serve de expressão a um em relação ao outro. Através da palavra, defino-me em relação ao outro, isto é, em última análise, em relação à coletividade. A palavra é uma espécie de ponte lançada entre mim e os outros (BAKHTIN, 1981, p. 113).

A epígrafe que abre este texto constrói-se a partir da palavra, mas aqui queremos 'ampliá-la'. O livro literário é produzido respondendo a uma demanda e dele emanam diversas possibilidades de interlocução, seja pela leitura livre, seja na investigação científica. Assim, a pesquisa empírica com crianças focalizada neste artigo pressupõe o diálogo e coloca em cena mais do que as faces das palavras ou das figuras, mas o fato de um sujeito se posicionar em relação ao outro - cada ser apresenta-se, afirma-se, liga-se, define-se em relação aos outros presentes numa determinada situação. O cenário e os atores nesta investigação surgem e efetivam-se como elementos vivos na constituição de identidades. 
Em ambiente da investigação que privilegiou o diálogo e a interação, definimos o nosso objetivo: investigar a leitura de narrativas visuais (presentes em obras integrantes de acervos - Educação Infantil do Programa Nacional Biblioteca da Escola [PNBE] 2014 - 4 e 5 anos), a fim de contribuir para os processos de letramento nessa faixa etária. A pergunta norteadora - como a criança de 4 anos atua no processo de construção de sentido de narrativa visual, a partir de situações de mediação planejadas intencionalmente? - foi o mote do estudo. No entanto, essa questão está interligada a outra, a ser pensada anteriormente: como as narrativas visuais, presentes em acervos para a Educação Infantil do PNBE - 2014, constituem-se, discursivamente, apelando ao seu destinatário?

Concomitante ao estudo teórico, realizamos a leitura de todas as obras da categoria narrativas por imagens selecionadas para estudantes de 4 e 5 anos $^{5}$, no intuito de definir critérios para escolha dos títulos empregados nessa análise. A pesquisa teve abordagem qualitativa e norteou-se a partir de:

1) seleção de cinco livros de narrativas de imagem do PNBE 2014 - Categoria 2. Educação Infantil - 4 a 5 anos - Acervos 1 e 2 para, posteriormente, serem trabalhados com grupo de 13 crianças com 4 anos em Escola de Educação Infantil que atende em turno integral. Os critérios para a definição dos títulos selecionados para a pesquisa foram que as obras se compusessem por imagens e as imagens deveriam compor uma narrativa;

2) análise dos livros, observando as peculiaridades acerca de elementos estruturais do gênero narrativa visual, qualidade do projeto gráfico-editorial, qualidade literária do texto e proposta de interação com o leitor, a partir de elementos estruturais presentes no enredo. Além disso, privilegiamos a análise da imagem, a fim de entender a significação da visualidade que tais narrativas geram, bem como os percursos construídos pelos leitores;

3) a investigação foi submetida ao Comitê de Ética e seguiu orientações legais para sua implementação. Posteriormente, formalizou-se o contato com a escola, para acertos sobre cronograma das sessões de leitura e a solicitação de autorizações, visando a parte empírica da pesquisa. Foram realizadas com as crianças sete sessões de leitura coletivas das obras selecionadas, sendo que uma das pesquisadoras atuou na mediação em todos os encontros. As sessões foram planejadas para serem independentes, ou seja, cada título foi trabalhado em encontro específico, com duração média de sessenta minutos, porém com flexibilidade,

5 Ladrão de galinhas, de Béatrice Rodrigues; Um+um+um+todos, Anna Göbel; Calma, camaleão!, Laurent Cardon; O gato e a árvore, Rogério Coelho; Minhocas comem amendoins, Elisa Géhin; Mar dos sonhos, Dennis Nolan; Voa pipa, voa, Regina Rennó; O noivo da ratinha, Lúcia Hiratsuka e Nerina: a ovelha negra, Michele Iacocca. 
respeitando o andamento e os interesses da turma. As sessões foram gravadas em áudio e vídeo, tendo em vista a importância do registro visual para a análise, não somente das falas das crianças, mas de suas manifestações, inclusive por meio do silêncio. Desse modo, planejamento das sessões de leitura, material de gravação, ficha de observação, diário de campo para anotações e registros e os próprios livros fazem parte do material de análise da pesquisa e, por último;

4) análise do material a partir de categorias que emergiram dos dados construídos, associadas ao quadro teórico, a etapa final que possibilitou a escrita desse texto interpretativo.

Para a investigação, foram utilizadas cinco obras integrantes do acervo do PNBE 2014, categoria 2 - Educação Infantil - Pré-Escola, conforme quadro 1:

Quadro 1 - Livros selecionados para pesquisa ${ }^{6}$

\begin{tabular}{|l|l|l|l|}
\hline \multicolumn{1}{|c|}{ TÍTULO } & AUTOR/ILUSTRADOR & EDITORA & ANO \\
\hline "Calma, camaleão"! & Laurent Cardon & Ática & 2010 \\
\hline "Ladrão de galinha" & Béatrice Rodriguez & Escala Educacional & 2009 \\
\hline "Nerina: a ovelha negra" & Michele Iacocca & Ática & 2012 \\
\hline "Um+um +um+todos" & Anna Göbel & Autêntica & 2013 \\
\hline "O gato e a árvore" & Rogério Coelho & Positivo & 2009 \\
\hline
\end{tabular}

Fonte: Elaborado pelas pesquisadoras

Tomaremos como recorte, neste artigo, o título "Ladrão de galinha", uma das obras integrantes do estudo maior. A partir dessa narrativa, constituída pela visualidade, serão discutidas particularidades do texto e aspectos atinentes à interação das crianças em sessão de leitura previamente organizada.

\section{Apresentação da obra}

"Ladrão de galinha”, de Béatrice Rodriguez, foi editado em 2005, na França, e, em 2012, no Brasil. Formado por 26 páginas com gramatura densa, favorece o manuseio. A trama, conforme paratexto situado na quarta capa, consiste na história de "uma raposa que sequestra uma galinha e foge. Personagens como o urso, o coelho e o galo a perseguem dia e

\footnotetext{
${ }^{6}$ No quadro 1, a editora informada é a que consta no Guia 1 - Literatura fora da caixa. Os livros utilizados na pesquisa não são os que foram enviados às escolas pelo PNBE 2014. Os exemplares foram adquiridos por uma das pesquisadoras, por isso na citação poderá constar outro ano e nas referências outra editora, conforme edição adquirida. Já o ano informado, a data foi retirada da ficha catalográfica dos exemplares manuseados na pesquisa. 
noite, por vales e bosques, atravessando o mar e o deserto. Até que, por fim, exaustos, chegam ao seu esconderijo, mas a galinha gosta da raposa e quer ficar em sua companhia"”.

Figura 1 - Capa "Ladrão de galinha”

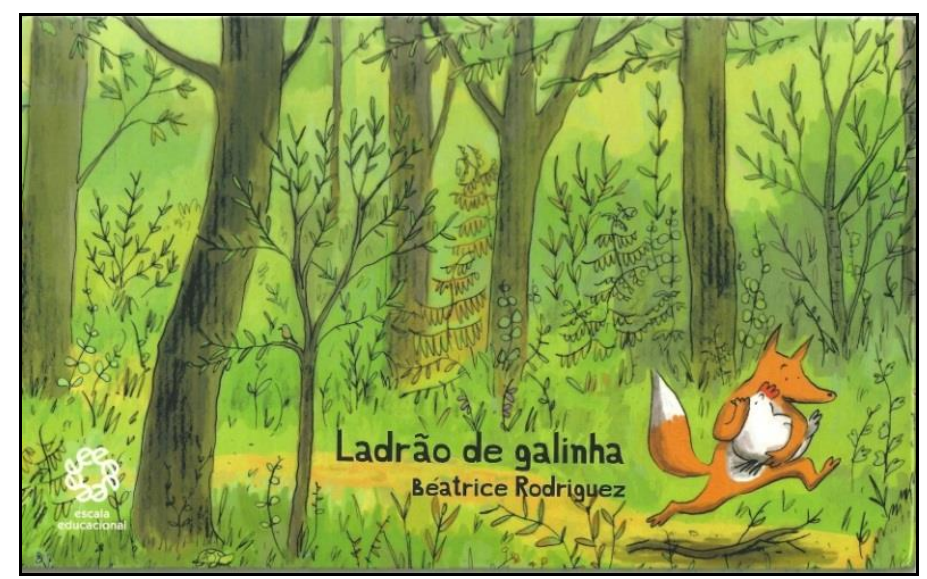

Fonte: Rodriguez (2009)

Na capa do livro (Fig. 1), situam-se o título e a ilustração. Pela imagem, é possível identificar personagens centrais e suas expressões: o movimento da cena é explícito pela ação de correr da raposa, que ocorre em ambiente externo, lembrando uma trilha no meio de um bosque. A cena sugere dinamismo.

O leitor também pode ter uma prévia noção do cenário pelos elementos presentes na capa. Ao abrir o exemplar e ver a totalidade da capa e da quarta capa (Fig. 2), constatamos mais uma parte da história. Na sequência, os outros personagens correm atrás da raposa que tem a galinha "nas mãos". Capa e contracapa, nesse caso, antecipam dados do enredo.

Figura 2 - Livro aberto: quarta capa e capa

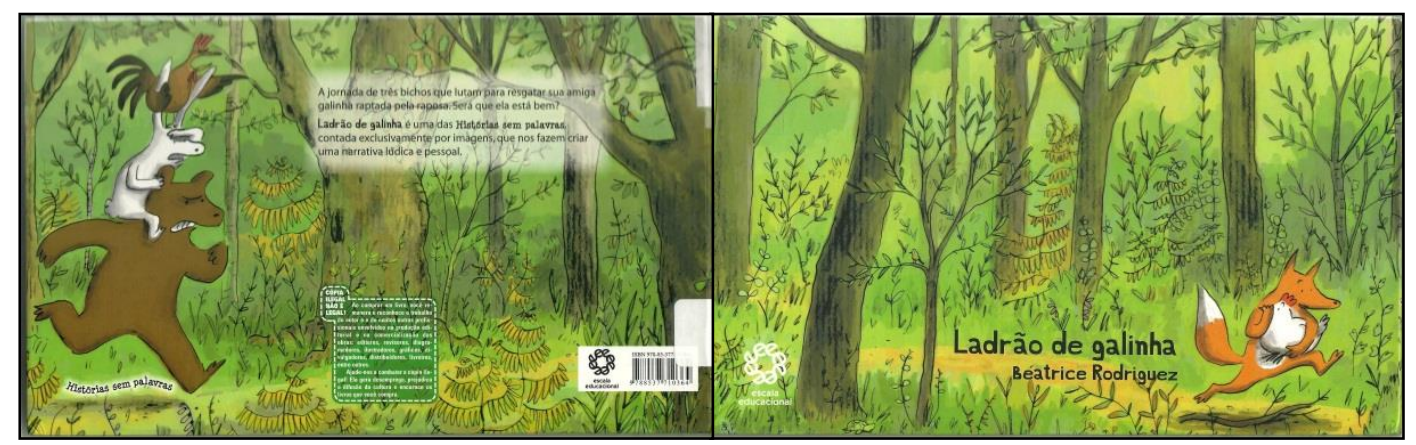

Fonte: Rodriguez (2009) 
O cenário campestre, anunciado desde a capa, reaparece na primeira página do livro. Elementos naturais da flora e animais executando ações humanas compõem as cenas. Estes, em posição ereta, deslocam-se caminhando com duas patas. A marcação de tempo é expressa, nessa cena, por movimentos como, por exemplo, abrir janela, bocejar, cantar do galo. Esses dados são indicadores de temporalidade constituídos pela imagem, ou seja, a experiência nos sugere que essas situações estão relacionadas ao amanhecer. Para Oliveira (2008, p. 53), “[...] ao visualizar a cena, automaticamente está sendo elaborado o tipo de cenário em que estão agindo os personagens". Nessa página, percebemos a situação inicial da história, porém um elemento, não tão explícito, anuncia o suspense que se concretiza na página ao lado. A raposa mostra-se escondida entre as plantas e observa os demais personagens - urso, coelho, galo, galinhas e pintos (Fig. 3).

Figura 3 - Situação inicial: equilíbrio da narrativa

Fonte: Rodriguez (2009, p. 1)

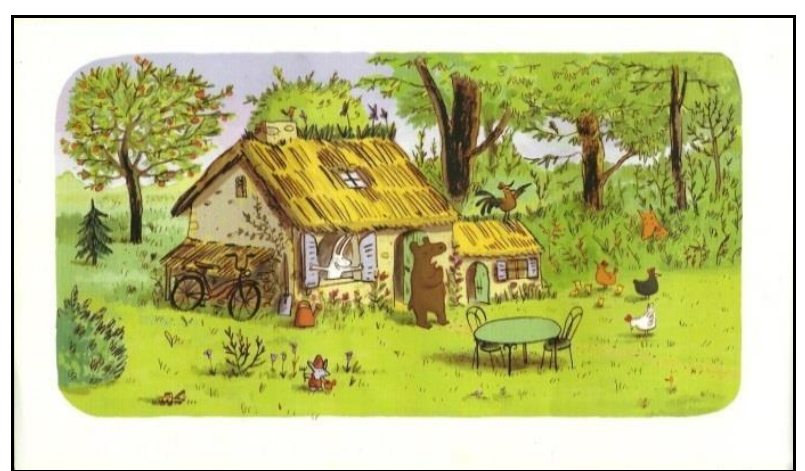

No cenário mostrado, a cor é elemento imprescindível para a compreensão da narrativa. Tons de verde predominam durante o percurso dos personagens na mata e a cor amarela na praia. A passagem do tempo também é demarcada por nuances de cor. O dia é sinalizado por tons mais claros, principalmente em amarelo e verde. Já a noite é indicada, predominantemente, com tons de azul e verde mais escuros. Segundo Oliveira (2008, p. 51), “[...] a qualidade de luz é um elemento importante no processo narrativo [...] a relação entre a cor e a luz é fundamental na arte de contar histórias visualmente”. Sem a presença da palavra, o leitor constrói a temporalidade por nuances cromáticas.

Na página 3 (Fig. 4), também se revela a cor verde em tom mais claro, indicando a luz do dia. Gradativamente, na cena seguinte (Fig. 5), o verde passa a ser mais escuro, sinalizando o anoitecer na mata (Fig. 6). 
Figura 4 - Verde claro (dia)

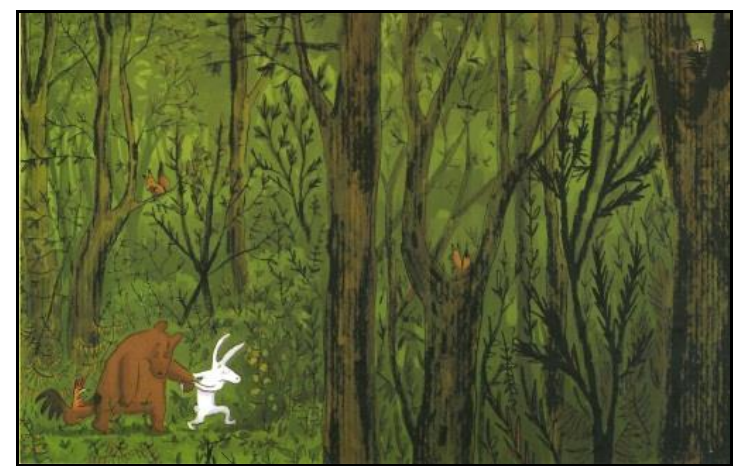

Fonte: Rodriguez (2009, p. 3)

Figura 5 - Verde escuro (noite)

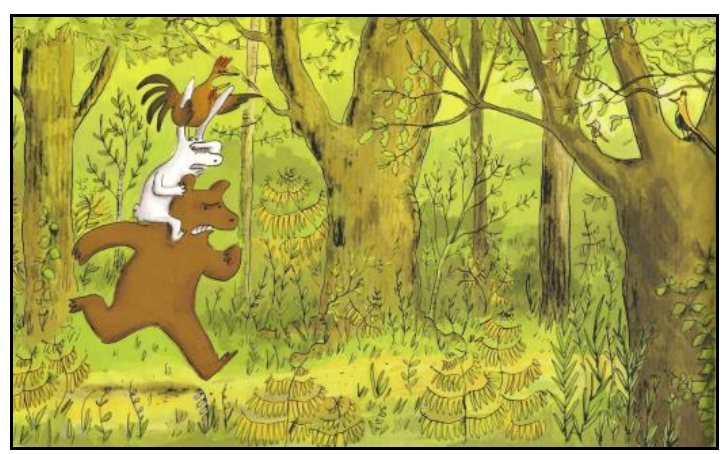

Fonte: Rodriguez (2009, p. 5)

Figura 6 - Lua indicando o anoitecer

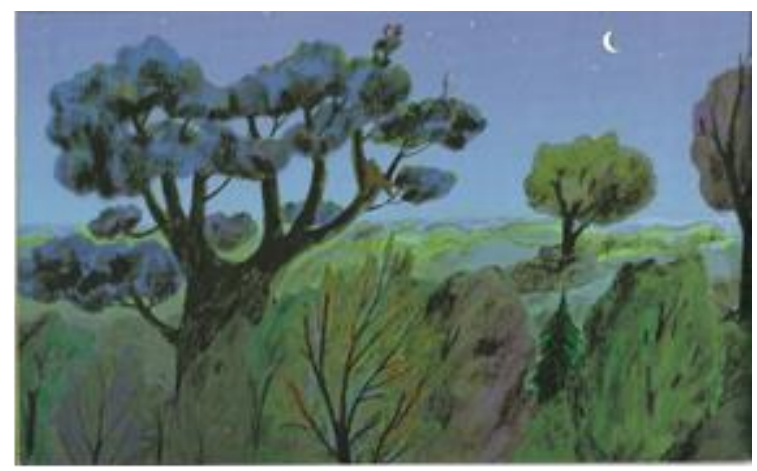

Fonte: Rodriguez (2009, p. 7)

No decorrer da história, o cenário, que, na situação inicial, era predominante a floresta, detalha aspectos do relevo pela figura da montanha, depois do mar e da praia. Os detalhes na composição do espaço favorecem a identificação do lugar onde atuam os personagens, assim como a elaboração do enredo. 
Há uma cena em que a raposa continua a fuga em direção ao mar e os outros personagens não hesitam em persegui-la. Ela apossa-se de um barquinho e começa a remar; a galinha, com óculos de sol, parece estar gostando do passeio. Já o coelho e o galo utilizam o corpo do urso como barco para navegar no mar, e a expressão dos três é de medo frente às ondas. Chegam à praia exaustos e avistam pegadas que levam a uma grande árvore onde fica a casa da raposa e da galinha. Pela janela, no tronco, os três tentam identificar o que há dentro. Entram com expressão de ira, o urso leva um pedaço de lenha na mão para se defender, no entanto, encontram a galinha e a raposa em harmonia, sentadas em frente à lareira, degustando sopa (Fig. 7).

Figura 7 - $\mathrm{O}$ encontro

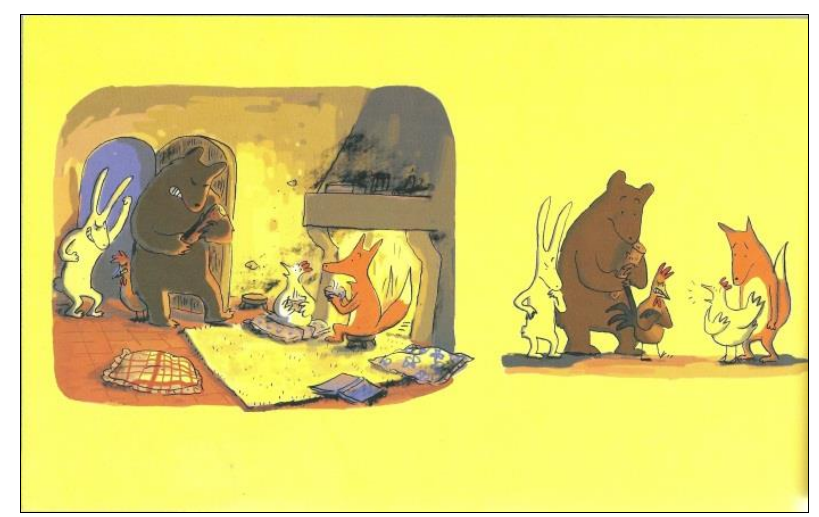

Fonte: Rodriguez (2009, p. 21)

Por fim, o desenlace ocorre no momento em que a galinha tenta explicar a situação e, então, beija a raposa. Em seguida, todos sentam-se ao redor da lareira para tomar sopa - a galinha está no colo da raposa, compartilhando o mesmo prato com expressão de felicidade. O galo não parece estar contente, e o urso mostra-se chateado.

Na última cena, em folha dupla, acontece a despedida, configurando-se o desfecho da narrativa. $\mathrm{O}$ urso, o coelho e o galo partem com o barco a remo e acenam para a raposa e a galinha que ficam na praia, satisfeitas. Na ilustração, a raposa volta-se para a esquerda, sugerindo ao leitor a possibilidade de retornar ao início da narrativa, ou seja, há proposição para a releitura da obra. Nessa imagem, o galo mostra-se cabisbaixo, fazendo o caminho de volta em companhia dos seus amigos (Fig. 8). 
Figura 8 - A despedida

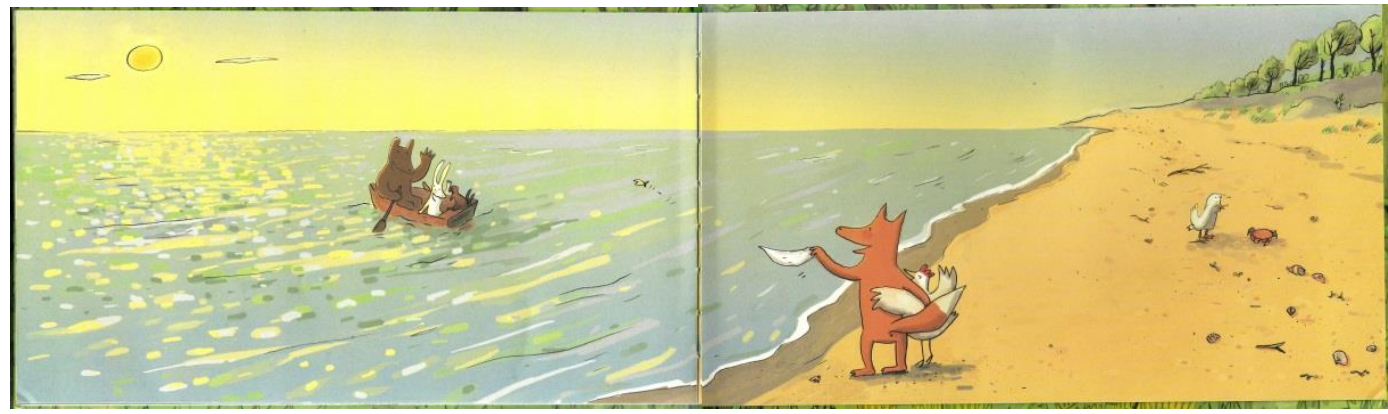

Fonte: Rodriguez (2009, p. 23-24)

Na última cena da narrativa, de acordo com a figura 8, a luz do sol refletida na água, a calmaria do mar e a linha do horizonte na parte superior das páginas retomam o equilíbrio observado no início da história, porém agora em outro ambiente, com a reorganização das relações entre os personagens, revelando a diversidade de cenários e de elementos naturais propostos ao leitor na dinâmica do livro.

Evidenciamos, na composição do enredo, a importância da cor e da luz nas cenas. Tais elementos, nesse caso, orientam o leitor acerca da passagem do tempo, aspecto constitutivo da narrativa e, desse modo, se percebidos pelo leitor, qualificam o entendimento da obra.

\section{Encontro dos leitores mirins com a narrativa visual}

Após a apresentação de aspectos atinentes à construção da história, priorizamos a interação das crianças com a obra. Nessa sessão, participaram 11 crianças da turma, sendo que para a intervenção foram utilizados quatro exemplares do livro. Os estudantes, na discussão dos dados, têm suas identidades preservadas e são referidos por nome fíctício, mas presentes no universo escolar.

A fim de dividir a turma em quatro grupos, confeccionamos quatro jogos de quebracabeças com 3 peças cada. As imagens formavam animais que são personagens da obra coelho, urso, galinha e raposa, porém foram utilizadas fotografias para a atividade. Nesse momento, as crianças ainda não tinham sido apresentadas ao livro. Aleatoriamente, cada aluno escolhia uma peça do quebra-cabeça e precisava encontrar os colegas que tinham as partes que faltavam para formar a figura. As crianças mostraram-se entusiasmadas durante a dinâmica. Atenção e raciocínio, acompanhados de ludicidade, permearam a organização dos grupos. 
Com os alunos agrupados, iniciamos oralmente a apresentação da obra e da autora. Em seguida, entregamos um exemplar para cada grupo $^{8}$ e observamos a interação das crianças entre si e com a narrativa, sem mediação da pesquisadora que acompanhou essa etapa. $\mathrm{Na}$ sequência, iniciamos a leitura oral e coletiva, quando a pesquisadora com um exemplar em mãos folheava-o para as crianças e, juntos, todos oralizavam a história.

Por último, propusemos a confecção de painel coletivo (Fig.9). Com papel pardo no tamanho de $1 \mathrm{~m} \times 1,50 \mathrm{~m}$, fixado à parede da sala, e uma caixa com diversos objetos, as crianças foram convidadas a explorarem os materiais e a criar, livremente, um painel sobre a história, a fim de representar aspectos do livro. Todas as crianças se envolveram na confecção da produção coletiva.

Figura 9 - Painel coletivo confeccionado pelas crianças

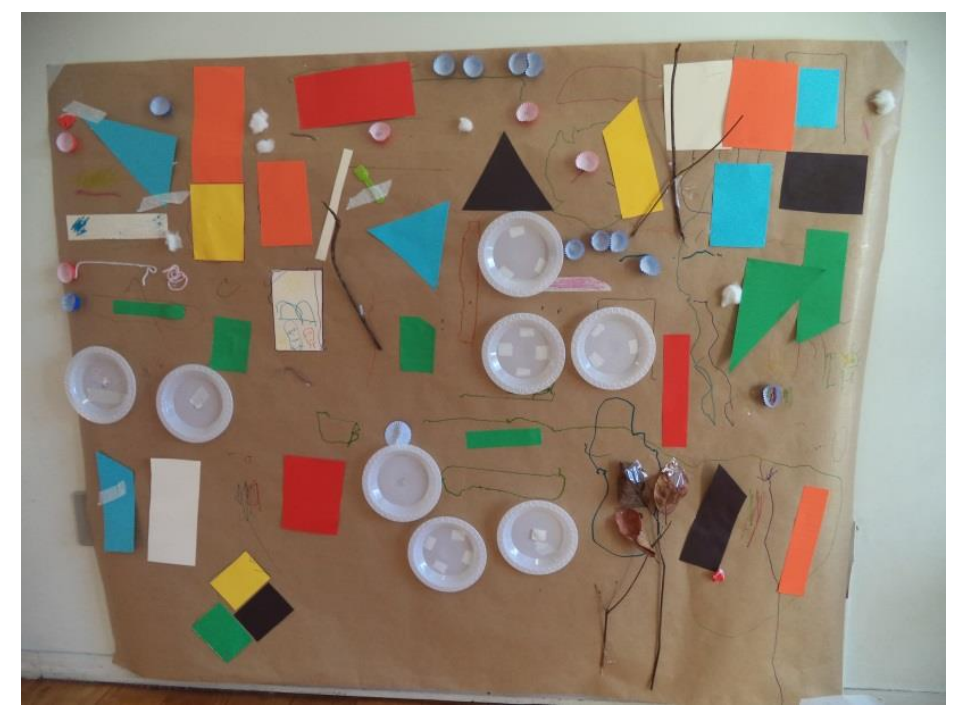

Fonte: Acervo da pesquisa

Empolgados com a atividade, os estudantes exploraram os materiais e ficaram, principalmente, entusiasmados com a diversidade dos materiais e, por vezes, remetiam aos personagens da obra, mencionando-os oralmente. O modo como as crianças organizam os elementos aponta aspectos iniciais relativos ao estabelecimento de inferências, de simbolização até chegar à produção de sentido para as composições criadas por meio da interação com os colegas.

${ }^{8} \mathrm{Nem}$ todos os momentos foram possíveis de serem filmados, uma vez que eram 4 grupos realizando a leitura simultaneamente e dispúnhamos apenas de duas filmadoras. Muitos dos registros desses momentos foram inseridos em planilha, durante e imediatamente após o encontro 


\section{Leitura das crianças: reflexões sobre interação e mediação}

No estudo da leitura partilhada do exemplar, elegemos como categorias de análise a interação entre os participantes da pesquisa e a ação-mediação da pesquisadora, de modo que serão trazidos para a discussão eventos relacionados às categorias indicadas, os quais serão analisados a seguir.

Durante a apresentação da obra, assim que mostramos a capa, Giz de $\mathrm{Cera}^{9}$ anunciou com empolgação: “- Profe! Profe! No canto caminhando! É uma raposa.” Mesmo sem saber o título do livro e do que tratava a história, a partir da visualidade, Giz de Cera imediatamente chamou a atenção do grupo para um elemento pontual no conflito. A indicação da criança “Profe!", e reforça: "Profe!" - evidencia espontaneidade ao expor a descoberta em relação ao foco da aula.

A narrativa contém muitos detalhes. Como as crianças tiveram a oportunidade de explorar o exemplar, anteriormente à leitura partilhada, interagiram conforme a percepção individual, porém consideraram as impressões de seus pares. Citamos o diálogo em que Giz de Cera refere-se à cena em que a raposa rapta a galinha: “- Daí a raposa fechou o bico da galinha." Para chegar a essa conclusão, a criança levou em conta a cena anterior, quando a raposa captura a galinha e ela "grita". A partir da observação da criança, a pesquisadora indaga: “- Por que ela fechou o bico dela?”; e, imediatamente, Aquarela complementou: “Porque a raposa não queria que a galinha ficasse com o bico aberto!”; Pincel sintetizou: “Ela fechou o bico porque não queria grito também." As crianças explicaram o fato a partir de conhecimentos prévios vividos em seus grupos sociais, uma vez que a visualidade do livro não trazia, explicitamente, esses dados.

É possível que, se não houvesse a pergunta do mediador que provocou as crianças a pensarem sobre a situação, Aquarela e Pincel não tivessem se manifestado sobre o fato de a raposa imobilizar a galinha. As crianças evidenciam, primeiramente, apenas o bico fechado, ou seja, a supressão da voz.

Em outra cena da narrativa, destacamos a expressividade e o faz de conta, elementos intrínsecos ao universo infantil, pois Pincel, ao ver a cena em que os personagens demonstram cansaço, após a fuga da raposa e a perseguição do galo, urso e coelho, conclui: “- E eles estavam cansados!" Mais do que as palavras, Pincel deita-se no chão como se estivesse dormindo. A cena pode ser explicada, porque nessa faixa etária “[...] constata-se ampliação do

${ }^{9}$ Utilizamos nomes fictícios para mencionarmos os sujeitos dessa pesquisa, a fim de preservar a identidade das crianças.

RIAEE - Revista Ibero-Americana de Estudos em Educação, Araraquara, v. 16, n. 4, p. 2609-2629, out./dez. 2021. e-ISSN: 1982-5587 
repertório de gestos instrumentais, os quais contam com progressiva precisão" (BRASIL, 1998, p. 24).

A possibilidade de demonstrar ao outro a sua compreensão frente à leitura daquela imagem possibilita ao mediador fomentar essa ideia. Assim, a pesquisadora continua: “Cansados. Olha!”, valorizando a expressão de Pincel. Na sequência, outras crianças expressam suas opiniões. Giz de Cera fala: “-E eu tô cansado de correr." Em seguida, a pesquisadora retoma, porém em tom questionador: "- Tu também tá cansado de correr?"; antes de Pincel responder, Lápis de cor interpela: “- Ah! Ele nem correu!” e Giz de Cera também participa da discussão, integrando-se ao conflito enfaticamente: "-Eu corri sim".

A conversa entre as crianças é retomada a partir de posição bakhtiana em que as pessoas, pela linguagem, definem-se em relação aos outros (BAKHTIN, 1981, p. 113). Frente à ideia lançada pela palavra de um indivíduo, outro pode complementar, concordar ou divergir. Na situação descrita, motivada pela visualidade do objeto cultural, as crianças divergiram ao se posicionarem verbalmente. Empregaram situação real, de cansaço por correr, de modo que cada um se expressou, conforme experiência anterior ou pela criação de um universo de faz de conta, comum nessa idade.

Nesse ponto, a mediadora percebeu como as crianças interagiam com a narrativa e entre si e, a partir das manifestações ou do silêncio, incitou perguntas, na maioria das vezes, desafiadoras.

Outra passagem na leitura partilhada do livro que destacamos refere-se à cena em que a raposa e a galinha já estão dentro da toca da raposa, e o urso os procura no ambiente externo, num morro. A pesquisadora indaga: "- $O$ urso conseguiu entrar no buraco?" e, prontamente, Papel Machê justifica: “-Não! Ele é muito grande.” A voz adulta insiste: “Ele é muito grande, não deu pra ele entrar, não é? e, imediatamente, na sequência, Giz de Cera conclui: “-Eu sou pequeno”, inserindo, explicitamente, sua condição para expressar o entendimento da cena. Vale destacar as peculiaridades no modo como cada criança interage com o livro e com os colegas e professora no sentido que constrói para a história.

As crianças dialogam, interagem entre si, e suas opiniões acerca do exposto emergem das suas vivências, do entendimento que têm de si, daquilo que compreendem naquele momento. Foi o que percebemos no diálogo anterior, em que, a partir da provocação da mediadora, Papel Machê conclui que o urso é muito grande, por isso não conseguiu entrar no buraco. Giz de Cera relaciona o ficcional exposto na imagem do livro à sua realidade, comparando seu tamanho ao do urso e deduz ser pequeno em relação ao animal. 
Outro diálogo das crianças diz respeito à inserção de um novo elemento espacial na narrativa, referindo-se às cenas em que a perseguição entre os personagens continua. Eles saem da mata fechada; a raposa sobe a montanha, momento em que a mediadora pergunta ao virar a página: “-E aí eles continuaram a perseguição, não é? E aonde será que eles estão? Será que é uma cidade?". Antes da pergunta, a pesquisadora afirma que eles continuam a perseguição, mas logo questiona sobre o lugar onde os personagens se encontram e, ainda, cita elementos que contrastam com o espaço que as crianças presenciam na cena. "- Será que é uma cidade?”. A problematização por meio da pergunta pode auxiliar as crianças a compreenderem e se posicionarem acerca da provocação docente.

Na sequência, Giz de Cera conclui: “- Não. É uma grama, Profe”. A expressão de negação imprimiu destaque à resposta, ou seja, para Giz de Cera, a cena em nada se parecia com a cidade e, sim, com a 'grama'. Para ele, citar a grama como novo cenário era suficiente para se fazer compreender. A pergunta inicial da mediadora mobiliza falas de várias crianças. Entre as opiniões, algumas concordam com os colegas, outras divergem, conferindo vivacidade ao cotidiano de sala de aula. Assim que Giz de Cera identificou que os personagens estavam numa grama, Tinta Guache pronunciou-se: “-É uma montanha.”. Logo, a mediadora solicitou para observarem quais seriam os argumentos: “- É uma montanha! Por que tu acha que é uma montanha?". Antes que a menina respondesse, Caneta Hidrocor aponta: “- Ali é uma grama." Tinta Guache, imediatamente, finaliza: “- Porque ele é alto”, respondendo à pergunta inicial da pesquisadora, referindo-se ao modo como o relevo se concretiza.

A função de mediar a leitura partilhada da narrativa visual não é de induzir o leitor mirim a ver com os olhos do leitor guia, mas provocar questões para que as crianças observem mais, que se atenham aos detalhes das imagens e, acima de tudo, que coloquem nessa leitura suas marcas. Cada criança mobiliza-se e atribui sentido ao visto, por meio da mediação da pesquisadora, e participa do processo, integrando-se às falas e às experiências dos seus pares.

$\mathrm{Na}$ continuação da leitura, os sujeitos definiram o cenário, e a mediadora ainda problematiza: "E o que a raposa tá fazendo?", ampliando a percepção das crianças do lugar para a ação do personagem, que está diretamente ligada às características da montanha. Logo, Aquarela relata: "Tá subindo a montanha." $\mathrm{Na}$ discussão das crianças entre grama e montanha, cada uma manifestou seu entendimento, e Aquarela finalizou o diálogo relacionando a ação da raposa e o lugar, que antes foi mencionado pelos colegas, como a montanha. 
Ainda destacamos outra vivência, a partir da interação e mediação angariada pela visualidade do objeto cultural. Durante a leitura partilhada, Giz de Cera direciona a atenção: “Profe! Aqui embaixo!” (apontando para o peixe que aparece dentro da água, na página 17). A mediadora, em seguida, retoma o novo elemento encontrado por Giz de Cera e confidencia: “Olhem o que Giz de Cera achou aqui dentro da água. O que é aqui?”. Mobilizadas pela pergunta, as crianças expressam-se e Pincel assegura: “Um tubarão!”, enquanto Papel Machê afirma: "Um peixe". Para estimular o posicionamento das outras crianças, a mediadora insiste: "O que será que é?" e Pincel reitera, novamente: "Um tubarão”. Empenhada em que as outras crianças expressem suas opiniões, outra vez, interpela: "O Pincel acha que é um tubarão. Quem mais acha que é um tubarão?".

As possibilidades de mediação nem sempre se mostram explícitas. $\mathrm{Na}$ interação com as crianças, e dependendo de como as ideias vão surgindo, a mediação pode tomar caminhos distintos, alterando-se conforme as intervenções dos sujeitos e de suas experiências. Possivelmente, Pincel afirma ser um tubarão logo que observa a imagem, por ter a informação ou experiência anterior que lhe dá subsídios para reconhecer a imagem de um tubarão. A presença de ondas seria pista para pensar que essas águas são do mar e nele vivem tubarões. Outra resposta poderia ter desencadeado outros caminhos para a vivência de leitura da cena.

Em seguida, as crianças começam a trazer novas opiniões. Caneta Hidrocor, por exemplo, contesta: "Não é um tubarão. Eu acho que é um peixe gigante”. Para justificar que não é um tubarão, pensamos que a menina conhece características do tubarão. Indica ser um peixe gigante, ou seja, para ela, a forma como esse animal se mostra no livro não é de um tubarão, mas de um peixe grande, revelando pensar que tubarão é pequeno. Para expressar que é gigante, talvez tenha usado como referência o tamanho desse peixe em relação ao urso ou aos peixes menores, ilustrados na página ao lado. Pincel comunga da posição de Caneta Hidrocor e pondera: "Eu acho que é um gigante”. Já Tinta Guache concorda com Pincel e sentencia: "É um tubarão”. No final do diálogo, Giz de Cera introduz outro elemento à discussão: "Eu acho que é um peixe espada", e Aquarela sintetiza, congregando posições dos colegas: "Eu acho que é um tubarão gigante com uma espada". A interação revela que as crianças observam formas, dimensões e também a proporcionalidade entre os seres representados.

O modo como as crianças interagem entre si, com o exemplar e com o mediador constitui-se momento ímpar. A diversidade de elementos expostos pela visualidade da narrativa desencadeia percepções, em que as crianças, juntas ao mediador e ao livro, exploram hipóteses, pesquisam, explicam e argumentam. Mesmo que, na leitura partilhada, os 
elementos constituintes da estrutura narrativa não tenham sido explicitamente definidos, houve por parte dos sujeitos reconhecimento dos personagens, cenários, noções de tempo e de espaço.

Com efeito, reiteramos a importância da percepção e da ação do mediador frente às posições das crianças. Referente à leitura mediada na faixa etária em que se destina esse estudo, Soares e Paiva (2014, p. 15) destacam que "[...] vale apostar numa relação mais cúmplice e aproximada, em que o mediador também escute as manifestações - palavras ou gestos - das crianças [...]". De fato, essa proximidade pela escuta atenta e solidária do mediador eleva o vínculo na interação, suscitando espontaneidade e encorajando a criança pequena a experimentar novas aprendizagens. Em síntese, os leitores mirins manifestaram curiosidade, espontaneidade e interação na leitura, de modo que a situação vivida implicou abertura do adulto para lidar com o novo, aquilo que não estava previsto.

\section{Composição da narrativa visual pelo olhar dos leitores mirins}

Na leitura partilhada do livro, observamos o envolvimento que a narrativa proporciona ao leitor. De modo dinâmico e detalhado, as ações dos personagens e a constituição do cenário formam e revelam o enredo. Quer seja por elementos naturais, quer por ação e expressão dos personagens, é possível identificar a sequência da história.

A leitura da obra iniciou-se antes de abrir o livro. Capa e contracapa do exemplar são consideradas, pois contêm elementos importantes na construção da história. Por esse motivo, no início da leitura partilhada, a mediadora convida as crianças a observarem a capa e a quarta capa, quando antecipam aspectos da história.

A pesquisadora convocou: "Vamos começar olhando a capa. O que tem nessa capa que parece ter relação com o título? O que vocês acham?'. Nesse momento, Aquarela pegou o livro das mãos da pesquisadora e começou a elencar os personagens ilustrados na quarta capa: "Tem um galo, coelho, urso e... (vira o livro para olhar a capa) e a raposa com a galinha”. Os colegas indicaram a presença da raposa.

O fato revela que, pela visualidade da capa e da quarta, as crianças apontam o que mais lhes chamou a atenção, nesse caso, os personagens. Inicialmente, os leitores mirins identificam o todo, para depois aterem-se a detalhes e descreverem ações, inspirados por experiências anteriores que possibilitaram reconhecer os animais presentes na narrativa.

Na sequência da leitura, nas páginas 1 e 2, as crianças apontam que os personagens estavam comendo, e a mediadora especifica: "Eles estavam comendo, mas eles estavam 
jantando?". A pergunta instiga a pensarem sobre elementos temporais, ou seja, que pistas estão presentes nas figuras que demarcam em qual momento do dia a situação inicial acontece? Imediatamente, Aquarela responde que estavam jantando, e a mediadora interpela: "Tu acha que eles estavam jantando? A gente janta de noite, né?”. Giz de Cera corrige: "Os personagens estavam almoçando".

Indagados se era dia ou noite, as crianças asseguram ser dia, porque tem o sol. Porém o sol não aparece explicitamente, então a mediadora problematiza: "Cadê o sol?", Pincel responde: "O sol tá escondido", e Aquarela complementa: "Igual a raposa”.

Talvez, nesse momento, a resposta esperada pela mediadora seria que eles estavam tomando café, já que, na cena inicial, os personagens bocejam, abrem a janela, sugerindo o acordar; logo, a refeição matinal. As observações culminam na inferência sobre o momento do dia. As cores, tons mais claros de verde, apontam o amanhecer, mesmo que o sol não esteja explícito na página.

Após as crianças identificarem o cenário, o 'mato', solicitamos que comparem as imagens das páginas 3 e 4 com as das páginas 5 e 6 , onde o cenário é praticamente o mesmo (o mato), porém há sutilezas nas expressões dos personagens e na alteração da tonalidade das cores, indicando a passagem do tempo e a progressão temática, expressa pela ação dos animais. A interação das crianças com o livro revela singularidades, como percebemos no diálogo a seguir:

\footnotetext{
Pincel - E ali tá o mato!

Pesquisadora - Tem o mato né? E o que vocês perceberam que mudou dessa página aqui (mostrando as páginas 3 e 4), para essa página aqui (páginas 5 e 6)?

Giz de Cera - Eles estão perdidos.

Pesquisadora - Mas o que aconteceu?

Aquarela - $O$ coelho disse pra eles ir rápido pra pegar a galinha que a raposa pegou.
}

O movimento de folhear as páginas e retornar para as anteriores consiste em exercício primordial para a compreensão da narrativa. O leitor tem a possibilidade de adiantar ou retroceder as páginas, a fim de observar elementos que chamaram sua atenção, ou então, identificar situações que poderiam ter passado despercebidas.

As ações dos personagens, ilustradas com detalhes nas expressões, são observadas pelas crianças. Ao relatar a atuação do coelho, Aquarela deduz que ele 'disse' para os demais companheiros irem mais rápido. Na imagem, o coelho aparece puxando o urso pelo braço, como se estivesse incentivando-o a continuar a perseguição. Concluem que os animais ficaram cansados, mas, na página anterior, demonstravam 'força'. Novamente, a expressão de 
disposição na corrida para resgatar a galinha demonstra força e determinação dos personagens.

O tempo da história é observado pelas crianças mais pela ação dos animais do que por nuances de cores. Novamente, elas percebem os seres e suas ações. Depois, as sutilezas que as cercam. Essa capacidade desenvolve-se à medida que as crianças capturam, por exemplo, variações cromáticas e seus contrastes.

Motivados pelas indagações da mediadora, os alunos descreveram a noite por visualizarem a lua e as estrelas no céu e apontam tais elementos nas cenas da narrativa. Expressaram-se com alegria, ao reconhecer elementos naturais que identificavam o período do dia. Para isso, outra vez, usaram o movimento de folhear o exemplar, avançando e recuando. O ler se traduz numa ação de ida e volta.

Noite e dia são explorados constantemente na narrativa, sinalizando a passagem do tempo. Nas cenas em que aparecem tons mais escuros e elementos naturais, característicos da noite, as crianças relatam que os animais estão dormindo, pois estão cansados. No entanto, quando surge o sol, mostram que 'amanheceu' e eles [os animais] estão fortes, ou seja, descansaram.

No percurso da leitura partilhada, os cenários foram percebidos pelos leitores. As crianças relatam quando os personagens chegam à praia e ainda inferem que 'amanheceu'. A percepção acontece porque, na página anterior, cena composta em duas páginas, encontramse: elementos naturais (lua, estrelas); ação dos personagens (raposa e galinha dormem) e as tonalidades mais escuras sinalizam o anoitecer. Logo, na página seguinte, a cena também é composta em folha dupla, mas a cor predominante é o amarelo, o sol aparece, explicitamente, e todos os personagens estão correndo.

Fica claro para o leitor que amanheceu, como observamos na interação que segue:

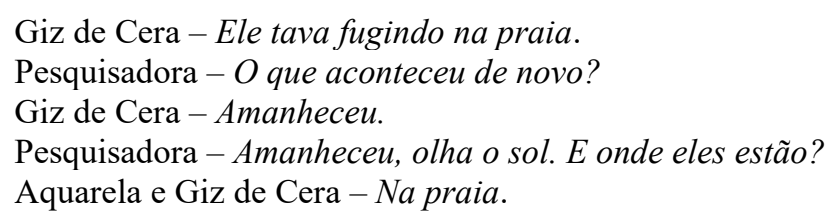

Novamente, as crianças identificam a mudança do cenário, no momento em que se inicia o desenlace. Dessa vez, o cenário não é externo, mas o interior da casa da raposa. $\mathrm{O}$ leitor chega a essa conclusão, porque na página anterior pode observar o lado externo da casa, onde urso, coelho e galo espiam a galinha e a raposa pela janela. Motivadas pela visualidade da narrativa, as crianças relatam, de forma clara, sua compreensão, principalmente no que diz respeito à atuação dos personagens, em consonância ao desfecho da história. 
Quadrantes, alguns fechados e outros abertos, com fundo amarelado, aparecem apenas nas páginas 21 e 22 . A observação da sequência dos quadrantes, da esquerda para a direita, e da expressão dos personagens auxilia na compreensão do desfecho da história. Mais uma vez, as crianças traduziram em palavras suas impressões sobre o enredo. O diálogo sintetiza a percepção dos sujeitos no final da leitura.

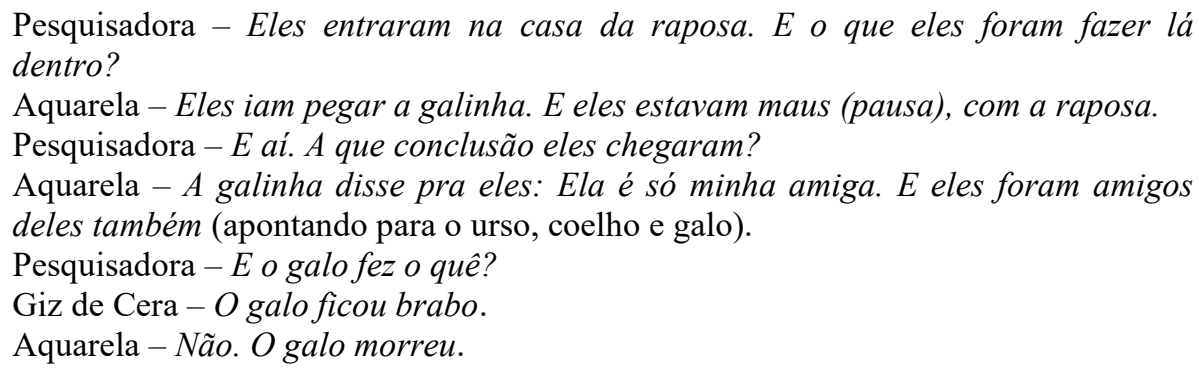

A sequência da narrativa culminou com o diálogo em que as crianças evidenciam sua compreensão sobre a narrativa, valendo-se de detalhes percebidos, cores, elementos naturais, ações, expressões, cenários, personagens. Mesmo que não expresso pela fala, mas pelo gesto, produziram sentidos para as imagens do exemplar. Cabe destacar a divergência de duas crianças sobre o desfecho da história, aspecto possível no entendimento do texto literário, o qual vem com final aberto para ser constituído a partir das vivências de cada leitor.

Os leitores mirins, na leitura partilhada, observaram, identificaram e relataram situações que explicitam a compreensão da narrativa a partir dos personagens e suas ações. Perceberam o cenário e suas alterações, conforme a dinâmica do enredo, assim como dados da temporalidade, ou seja, a passagem do tempo construída pelas nuances de cores e pela representação de elementos naturais, ora explícitos nas imagens como sol e lua, ora implícitos.

\section{Considerações finais}

Que aspectos deveriam ser considerados em situações de mediação docente com crianças de 4 anos? Que elementos seriam priorizados na mediação de uma obra literária constituída por imagens? Essas questões nortearam a empiria dessa pesquisa sobre leitura da narrativa visual.

$\mathrm{Na}$ leitura do texto visual do exemplar escolhido, observamos a percepção dos meninos e das meninas acerca de várias imagens. A observação de cada página põe em tela comentários das crianças, na maioria das vezes, motivados pelas provocações da mediadora. 
O mediador percebe as sutilezas das vivências dos interlocutores e acolhe-as, ajudando-os a 'ver'.

Apesar da clareza sobre o papel da mediação de leitura, entendemos que essa faz parte da interação, que é maior. Enquanto o mediador cumpre sua atribuição de contribuir para efetivar a leitura coletiva, também está interagindo com o livro e com os leitores. Da mesma forma, os estudantes interagem com a obra, com os seus colegas e com o mediador.

Na mediação da leitura partilhada da narrativa visual, o mediador não assume o papel de narrador da história. Se assim for, a leitura será conduzida pelas impressões do professor e não pelas potencialidades do livro ou do repertório dos leitores mirins, de modo que a recepção por parte das crianças tenderá a ser passiva, consequentemente, com restrito levantamento de hipóteses e de construção de sentidos pelos leitores iniciantes. O leitor (mirim) é coautor do texto, de modo que a ação docente criaria condições para que a leitura (das crianças) seja um exercício de autoria.

Quanto à repercussão da obra para os integrantes da pesquisa, apontamos que na sessão de leitura posterior à aqui analisada, no momento da acolhida, ao sentar em "roda", Giz de Cera indaga: “Cadê o livro "Ladrão de galinha?” e a pesquisadora responde: "Hoje o livro 'Ladrão de galinha' ficou na biblioteca, eu trouxe outro'. O fato de a criança lembrar-se do título, no início da conversa, remete à importância de proporcionar situações de encontro com a literatura, com manuseio do objeto livro, desde a mais tenra idade. Provavelmente, a leitura do exemplar citado possibilitou experiências relevantes à criança, a ponto de indicá-lo no encontro seguinte. A resposta da mediadora não deixou a pergunta sem resposta, muito menos enunciou monossílabo "não". Trouxe à tona outra experiência leitora, a existência de bibliotecas como local onde podemos encontrar livros e, ainda, introduziu informação nova, o acesso a outra obra.

No conjunto da narrativa, entendemos que a visualidade (construída na espacialidade) tem lacunas que são preenchidas pelas vivências dos leitores e que a leitura do livro inicia antes de abrir o exemplar. No caso em destaque, hipóteses acerca da história foram elaboradas a partir da observação da capa e da contracapa. No que tange aos elementos estruturais da narrativa, a ausência da palavra exige que o leitor construa, por exemplo, a temporalidade e a espacialidade do enredo por meio das figuras. Pelas perguntas, o mediador problematiza e ensaia caminhos possíveis de leitura, instrumentalizando os discentes a atuar de modo autônomo quando forem ler outras obras literárias.

Em síntese, na leitura da narrativa visual, em ambiente coletivo, a criança lê as imagens a partir de suas experiências e de seu conhecimento de mundo, porém sua atuação é 
ampliada e potencializada na interação com o outro (colegas e professor). Na situação vivida, retomando epígrafe deste artigo, as crianças vão se colocando em relação aos outros da situação enunciativa criada. Pela linguagem, pontes vão sendo edificadas, e o sentido do texto e dos sujeitos vai se desenhando, se materializando gradativamente. A leitura, no âmbito dessa pesquisa, faz-se pelo movimento de avanço e recuo no exemplar como também pela provocação do outro (professor ou colega) sobre os rumos da narrativa. Ou seja, a leitura com crianças pequenas é uma experiência solidária.

\section{REFERÊNCIAS}

BAKHTIN, M. Marxismo e filosofia da linguagem. São Paulo: Hucitec, 1981.

BRASIL. Ministério da Educação e do Desporto. Secretaria de Educação Fundamental. Referencial Curricular Nacional para a Educação Infantil. Volume 1: Introdução; Volume 2: Formação pessoal e social; Volume 3: Conhecimento de mundo. Brasília, 1998.

BRASIL. Programa Nacional Biblioteca da Escola. Disponível em: http://www.fnde.gov.br/programas/biblioteca-da-escola/biblioteca-da-escola-historico. Acesso em: 14 set. 2015.

OLIVEIRA, R. Pelos jardins Boboli: reflexões sobre a arte de ilustrar livros para crianças e jovens. Rio de Janeiro: Nova Fronteira, 2008.

PAIVA, A.; SOARES, M. Introdução. PNBE na escola: literatura fora da caixa. Guia $1 /$ Ministério da Educação; elaborada pelo Centro de Alfabetização, Leitura e Escrita da Universidade Federal de Minas Gerais. Brasília, DF: Ministério da Educação, Secretaria de Educação Básica, 2014. Disponível em:

http://portal.mec.gov.br/index.php?option=com_docman\&view=download\&alias=15609guia-ei-leituraforadacaixa-pdf\&category_slug=maio-2014-pdf\&Itemid=30192. Acesso em: 20 abr. 2018.

RODRIGUEZ, B. Ladrão de galinha. São Paulo: Escala Educacional, 2009. 


\section{Como referenciar este artigo}

LORENZET, F. L.; RAMOS, F. B.; SOUZA, R. J. Narrativa visual: mediação de leitura na educação infantil. Revista Ibero-Americana de Estudos em Educação, Araraquara, v. 16, n. 4, p. 2609-2629, out./dez. 2021. e-ISSN: 1982-5587. DOI: https://doi.org/10.21723/riaee.v16i4.13624

Submetido em: 11/07/2021

Revisões requeridas em: 09/08/2021

Aprovado em: 10/09/2021

Publicado em: 21/10/2021 